\title{
Resenha
}

\section{Freud: releituras brasileiras}

\author{
Jair Knijnik*
}

O projeto Freud: releituras brasileiras, levado ao Rio Grande do Sul a partir de agosto de 2002, desenvolveu, entre outras atividades, dois ciclos: o primeiro, sob a forma de palestras abertas à comunidade, abordou as relações da psicanálise com a sexualidade, a cultura, a história, os mitos, a filosofia, a literatura e a comunicação; o segundo, também aberto à comunidade, constou de debates sobre os filmes de Alfred Hitchcock, sob os vértices psicanalítico e cultural.

Esse livro, organizado pelos psicanalistas Mauro Gus, Jussara Schestatsky dal Zot e Ida loschpe Gus, editado pela Casa do Psicólogo, em 2003, apresenta esses ciclos sob a forma de uma publicação. Sua leitura é agradável e consistente. É enriquecedor tanto para o público leigo interessado em temas ligados à psicanálise aplicada a outras áreas do conhecimento humano, quanto para o público especializado. Apresenta textos com uma linguagem clara, acessível e que promovem a reflexão na mente do leitor sobre questões atuais e importantes da psicanálise em relação à cultura.

O "penso logo existo" foi substituído pelo "existo onde não penso". Estava fundada a no-

\footnotetext{
* Sócio efetivo da SPRS.

Candidato do Instituto de Psicanálise da SPPA.
}

ção de inconsciente, tão fundamental para o pensar psicanalítico. A palavra, ao mesmo tempo reveladora, também ocultava outro significado, da mesma forma que um sintoma ou um sonho.

Este trecho extraído do primeiro capítulo, intitulado Psicanálise e sexualidade, penso que transmite o espírito do livro: a ambigüidade das manifestações humanas, portadoras de inúmeros significados. Nesse primeiro capítulo, também é apresentado o desenvolvimento da Teoria Sexual na obra de Freud: as fases do desenvolvimento libidinal, a universalidade do Complexo de Édipo, o Narcisismo, o dualismo pulsional e a interdição do incesto.

Há um cuidado dos autores dos diversos capítulos, como veremos a seguir, de não descreverem a psicanálise como uma explicação "definitiva e única" para as manifestações da cultura e da existência humana, mas como mais um vértice para olhar e compreender os fenômenos culturais.

A escolha homossexual nas relações humanas: opção ou doença? - o autor aborda um tema polêmico, salientando inicialmente três disposições sociais frente ao tema do homossexualismo: ser radicalmente contra, chegando-se inclusive à violência; grupamentos homossexuais que se articulam realçando as 
pretensas virtudes da atividade sexual homossexual e uma terceira posição, na qual há um "tom" de "cada um faz o que quer", ou de que essa é uma opção sobre a qual cabe a cada um decidir. Aborda o tema vinculando a manifestação sexual adulta à sexualidade infantil, realçando que cada um não faz o que quer, mas "Cada indivíduo faz o que pode quanto à sua vida e conduta sexual, segundo uma complexa interação de influências biológicas, evolutivas, intrapsíquicas, relacionais e culturais."

Psicanálise e cultura: um diálogo em construção - aborda com maestria tanto o ponto de vista da cultura influenciando a psicanálise , a Viena do fim do século XIX, as peculiaridades do fazer psicanalítico em diferentes ambientes culturais: América Latina, América do Norte, França, Inglaterra, etc, como também a contribuição que a psicanálise tem a dar à reflexão sobre a cultura atual - a imagem predominando sobre a imaginação, por exemplo. Os mitos e lendas brasileiros estudados sob o vértice psicanalítico também são realçados. O capítulo finaliza tentando responder a uma pergunta central: o que a psicanálise oferece? "Ela oferece um espaço para o pensar crítico, ela oferece uma visão crítica, subversiva, não suscetível a qualquer domesticação convencional na busca dos significados inconscientes dos fenômenos individuais e coletivos".

Psicanálise e filosofia - traz um panorama dos principais pensadores psicanalíticos, que dão origem às várias escolas psicanalíticas. Existe uma pergunta corrente: há uma ou várias psicanálises? O autor, com propriedade, aponta alguns conceitos básicos, que, quando presentes, formam o conceito de psicanálise: inconsciente, determinismo psíquico, noção de pulsões ou relações de objeto, transferência e associação livre.

Psicanálise e história - não poderia ser mais oportuno! O autor centra a sua discussão a partir de uma carta que Freud envia a Einstein, intitulada "Por que a guerra?" Einstein questionara-Ihe se existiria algum meio de livrar os homens da ameaça da guerra; se seria possível canalizar a agressividade dos seres humanos no sentido de protegê-los contra os impulsos de ódio e destruição.

Mito e psicanálise: Édipo diante da esfinge - realça inicialmente o fato de que Freud forjou um olhar e uma linguagem que permitem ver e dizer as coisas do corpo e da sexualidade, dando-Ihes cidadania, respeitabilidade e seriedade. Propõe-se a revisitar o mito de Édipo, enfocando o episódio da Esfinge. sobre psicanálise e mitos na realidade atual Freud salientava que os mitos mostram uma "ignorância consciente e uma sabedoria inconsciente". Os Gregos utilizavam duas expressões para definir palavra ou conhecimento: logos, equivalente à razão e mythos, que significa definir com um enunciado decisivo, sem se justificar, como nas religiões. O ser humano precisa desses dois sistemas de apreensão da realidade para sobreviver emocionalmente. O mito é simbólico, oculta e revela simultaneamente. $\mathrm{O}$ analista deve flutuar entre logos e mito. Finaliza comentando acerca dos pacientes atuais, das patologias do vazio, dos sintomas somáticos, relacionados à ausência de mitos, requerendo maior atenção do analista às suas próprias sensações na " cena da sessão" para a construção de alguma comunicação simbolizante, ligada à palavra.

Comunicação e psicanálise -Sobre a questão das massas ou das multidões. A relação do indivíduo com a multidão, o líder, a energia instintiva que leva aos fenômenos sociais. Assinala as contribuições do pensamento freudiano no campo político, no estudo da psicopatologia do totalitarismo.

Psicanálise e comunicação - enfoca o discurso do paciente com o analista, a questão da metalinguagem. "A linguagem, como um todo, envolve o corpo, a postura, a apresentação, o afeto, o momento e tantos outros elementos , diante dos quais a palavra torna-se uma coadjuvante do ato de comunicação." Alerta que, quando se busca a segurança de conhecimentos, de métodos rígidos para apreender um objeto de estudo, corre-se o risco de deixar sobrar muito desse objeto, de tudo aquilo que o método não pode dar conta.

Psicanálise e literatura - discute a questão da interpretação psicanalítica das obras literárias. Traz questionamentos acerca das possibilidades de explicar-se o dom artístico, a interpretação psicanalítica de traumas ou da neurose do autor a partir de sua obra, das diferenças de interação do leitor, ainda que psicanaliticamente informado, com o texto e do analista com o seu paciente. O texto não confirma ou refuta as suas interpretações, diferentemente do relacionamento terapêutico. A literatura e a psicanálise são duas ordens diversas de produção simbólica, cada uma com seus direitos e estatutos próprios e inconfundíveis.

Psicanálise e literatura: Goethe e Freud: algumas pétalas no Grand Canyon - Em 1930, Freud foi agraciado com o prêmio Goethe, pelo conjunto de sua obra, o que demonstra desde logo a profunda relação da psicanálise com a 
literatura. É descrita a admiração de Freud pelos escritores e poetas, assim como pela própria literatura. Nos Três Ensaios sobre a Teoria da Sexualidade, de Sigmund Freud, há citações literárias, que inspiram e corroboram suas observações teórico-clínicas, demonstrando que se tratavam de manifestações inerentes à natureza humana e já observadas anteriormente por artistas sensíveis. Neste caso, a citação literária é do próprio Goethe, num trecho em que Freud exemplifica o fetichismo. Isto posto, o autor do capítulo conclui que a aproximação da literatura com a psicanálise dá-se pelo fato de ambas emprestarem palavras para darem expressão verbal aos sentimentos que nos impactam em nosso dia-a-dia.

A parte II do livro é sobre o ciclo de cinema e debates Alfred Hitchcock. Consta de 16 capítulos que versam sobre os seguintes filmes: Vertigo - um corpo que cai, Janela Indiscreta, Disque $\mathrm{M}$ para Matar, Os pássaros, Pacto $\mathrm{Si}$ nistro, Festim Diabólico, Marnie: confissões de uma ladra e Frenesi. Cada filme é comentado por um cineasta e por um psicanalista, o que complementa a discussão.
O livro finaliza apresentando o trabalho premiado pelo projeto Freud: releituras brasileiras, intitulado As pulsões e a aventura do ser e do acontecer. Nesse trabalho, o autor relaciona e comenta a Teoria pulsional de Freud com as correntes filosóficas. Perpassa as noções de pulsão, sujeito e objeto, aproximando-as da dialética do pensamento de Hegel.

Freud: releituras brasileiras, em seu conjunto, cumpre um objetivo significativo, qual seja o de demonstrar, com simplicidade e consistência, a influência viva do pensamento freudiano e da psicanálise na cultura contemporânea, assim como a influência viva da cultura na própria psicanálise. Uma influenciando a outra e sem a outra existindo apenas como uma possibilidade hipotética.

\author{
Endereço para correspondência: \\ Jair Knijnik \\ Rua Dr. Alcides Cruz, 465/24 \\ 90630-160 - Porto Alegre - RS \\ Copyright () Revista de Psiquiatria \\ do Rio Grande do Sul - SPRS
}

